\title{
SŁAWOMIR DOROCKI
}

Uniwersytet Pedagogiczny w Krakowie, Polska

Pedagogical University of Cracow, Poland

\section{PIOTR RAŹNIAK}

Uniwersytet Pedagogiczny w Krakowie, Polska

Pedagogical University of Cracow, Poland

\section{ANNA WINIARCZYK-RAŹNIAK}

Uniwersytet Pedagogiczny w Krakowie, Polska

Pedagogical University of Cracow, Poland

\section{Zmiany funkcii kontrolno-zarzq̨dzzych w miastach europejkich w dobie globalizacii}

\section{Changes in the Command and Control Functions in European Cities in the Age of Globalisation}

\begin{abstract}
Streszczenie: Celem artykułu jest analiza zmian wartości funkcji kontrolno-zarządczej ośrodków miejskich w latach 2006 i 2012 w oparciu o metodę centrów grawitacji. Zakres czasowy analizy obejmował okres światowego kryzysu gospodarczego oraz zależny był od dostępności danych. Analizę przeprowadzono zarówno dla poszczególnych sektorów gospodarki, jak i dla międzynarodowego wskaźnika potencjału (MWP). Na podstawie użytego wskaźnika MWP zauważono przesunięcie środka ciężkości funkcji kontrolno-zarządczej miast w kierunku wschodnim. Współcześnie, głównie w wyniku rozwoju obszarów Europy Środkowo-Wschodniej oraz postępującej integracji europejskiej (wzrastającej w kierunku wschodnim i południowym), następuje wzrost znaczenia lokalnych przedsiębiorstw w krajach rozwijających się. Można stwierdzić, że nastąpił wzrost znaczenia funkcji kontrolno-zarządczej miast w krajach rozwijających się (Rosja, Polska). Zaobserwowano spadek znaczenia tzw. niebieskiego banana (blue banana), a przede wszystkim ośrodków brytyjskich i niemieckich. Szczególnie widoczne jest to pod względem zwiększenia się liczby siedzib zarządów na wschodzie kontynentu. Jednakże przemieszenie kapitału nie jest aż tak wyraźne i w dalszym ciągu korporacje niemieckie i brytyjskie pozostają zdecydowanymi liderami w Europie.
\end{abstract}

\begin{abstract}
The aim of the study is to analyse the changes in the command and control functions of cities in 2006 and 2012 based on the method of gravity centres. The analysis was performed both for individual sectors of the economy, as well as for European ones. On the basis of the International Potential Indicator, the shift of the centre of gravity of the command and control functions of cities to the East was noted. Nowadays, mainly due to the development of Central and Eastern Europe and the progressive European integration (rising to the East and South), the relocation of many companies from West to East and the growing importance of local companies in developing countries are increasing. It can be said that the importance of the command and control functions of cities in developing countries has increased (Russia, Poland). There was a decline in the importance of the blue banana region and British and German cities. This is especially visible in terms of the number of headquarters in the Eastern part of the continent. However, the capital shift is not that clear and the German and British corporations still remain strong leaders in Europe.
\end{abstract}

Słowa kluczowe: funkcja kontrolno-zarządcza miast; korporacje międzynarodowe; model grawitacyjny; siedziby zarządów

Keywords: command and control function; gravity model; headquarters; transnational corporation 
Otrzymano: 19 grudnia 2017

Received: 19 December 2017

Zaakceptowano: 29 czerwca 2018

Accepted: 29 June 2018

Sugerowana cytacja / Suggested citation:

Dorocki, S., Raźniak, P., Winiarczyk-Raźniak, A. (2018). Zmiany funkcji kontrolno-zarządczych w miastach europejskich w dobie globalizacji. Prace Komisji Geografii Przemysłu Polskiego Towarzystwa Geograficznego, 32(3), 128-143. https://doi.org/10.24917/20801653.323.8

\section{WSTĘP}

Uważa się, że siłę miasta na arenie międzynarodowej można mierzyć na wiele sposobów. Oprócz inwestycji napływających i wypływających z miasta, świadczących o znaczeniu międzynarodowych firm, pod uwagę można wziąć liczbę zatrudnionych w nich pracowników lub kapitał firm. Przypuszcza się również, że nierówności w przepływie kapitału międzynarodowego mówią więcej o pozycji miasta w systemie globalnym niż pozycja poszczególnych spółek zależnych od niewielkiej liczby firm partnerskich. W jednej z siedmiu hipotez koncepcji world city stwierdza się, że globalne funkcje kontrolne międzynarodowych korporacji są bezpośrednio związane z działalnością sektora produkcyjnego (Friedmann, 1986), jednakże nowsze podejście do koncepcji world city pokazuje, że to firmy usługowe lepiej ukazują powiązania międzynarodowe miast (Beaverstock, Smith, Taylor, 1999).

We współczesnym zglobalizowanym świecie zmniejsza się znaczenie odległości w przemieszczaniu się siły roboczej i środków finansowych. Pojawia się zatem tendencja prowadząca do powstania międzynarodowego systemu gospodarczego oraz zwiększają się powiązania między korporacjami, jak i samymi miastami (Sassen, 2000). Można zatem stwierdzić, iż funkcja kontrolno-zarządcza (KZ) w miastach jest podstawowym elementem niezbędnym do zrozumienia ich roli w dobie globalizacji (Ni, Taylor, Derudden, 2011). Według G. Csomósa (2013) funkcje kontrolno-zarządcze miast może pełnić 2000 firm umiejscowionych na liście Forbes Global 2000 (Forbes, 2013).

We współczesnym świecie miasta dążą do poprawy swej konkurencyjności i pozycji (Begg, 1999). Wraz z intensyfikacją procesu integracji europejskiej zanikają różnice w poziomie rozwoju gospodarczego pomiędzy poszczególnymi krajami. Przełożyło się to na przeniesienie konkurowania z poziomu międzypaństwowego na poziom miast i regionów (Storper, 1995). Europejska polityka spójności w znacznym stopniu przyczyniła się do zmniejszenia rozbieżności między bogatymi a biedniejszymi krajami. Niemniej jednak nowe państwa członkowskie borykają się z coraz większymi różnicami rozwoju dużych miast w stosunku do mniejszych ośrodków i terenów wiejskich (Kramar, 2006). Ta tendencja zwiększa znaczenie lokalnych uwarunkowań, które mogą być czynnikiem przyciągającym międzynarodowy kapitał, korporacje, inwestorów i turystów (Parkinson, Hutchins, Simmie, Clark, Verdonk, 2004). Jednym z ważnych elementów tego procesu jest zwiększanie swojej ekspansji poprzez przejmowanie innych podmiotów gospodarczych lub też lokowanie części swojej działalności w krajach o niższych kosztach pracy (Zioło, 2006; Kilar, 2009). Dzięki temu wiele miast Europy Wschodniej zostało włączonych w międzynarodowy system ekonomiczny przez zlokalizowanie w nich międzynarodowych firm (Domański, 2004; Raźniak, Dorocki, Winiarczyk-Raźniak, 2018). 
W literaturze specjalistycznej znajdziemy wiele przykładów zilustrowania przestrzennego zróżnicowania rozwoju społeczno-ekonomicznego w Europie. Jedną z pierwszych prób był european backbone (Brunet, 1989), nazywany później blue banana, umiejscowiony w środkowej części Europy Zachodniej. Mimo upływu ponad dwóch dekad jego kształt się nie zmienił i nadal rzeczony region dominuje gospodarczo w Europie (Kincses, Nagy, Tóth, 2013). Podobna struktura, zwana Central European Boomerang, znajdująca się w Europie Środkowo-Wschodniej, uważana jest za najbardziej rozwinięty region tej części kontynentu (Gorzelak, 1996), gdzie wyraźnie dominuje Warszawa i Praga (Raźniak, Dorocki, Winiarczyk-Raźniak, Płaziak, Szymańska, 2017). Z kolei inną koncepcję przedstawili M. Wegener i K.R. Kunzmann (1996), nie zgadzając się z wyznaczeniem blue banana jako dominującego regionu w Europie. Twierdzą oni, że struktura kontynentu jest policentryczna i oparta na rozłożonych dosyć równomiernie, silnych regionach metropolitalnych.

We współczesnej literaturze przedmiotu istnieją badania z zastosowaniem centroidów dla świata i poszczególnych kontynentów według PKB wybranych krajów i miast (Tóth, Nagy, 2017) czy też pod kątem ich funkcji kontrolno-zarządczej (Csomós, Tóth, 2016). Nie ma jednak szczegółowych badań przesunięć centroidów na podstawie wyników finansowych firm w skali europejskiej, a zwłaszcza funkcji kontrolno-zarządczej według sektorów. W związku z tym celem artykułu jest wyznaczenie środka grawitacji dla funkcji kontrolno-zarządczej ośrodków miejskich w latach 2006 i 2012, zarówno dla poszczególnych sektorów gospodarki, jak i dla europejskiego syntetycznego wskaźnika potencjału. Określenie przesunięcia potencjału finansowego firm dla poszczególnych sektorów gospodarki może ukazywać siłę poszczególnych regionów gospodarczych na świecie oraz zmianę znaczenia tych regionów w globalnej gospodarce.

\section{METODA}

W celu określenia ekonomicznej wartości funkcji kontrolno-zarządczych poszczególnych miast stworzono sektorowy międzynarodowy wskaźnik potencjału (sMWP) [1]. Wskaźnik oparty został na standaryzowanych wartościach: przychodów, zysków, aktywów oraz wartości rynkowej dla poszczególnych sektorów gospodarki z uwzględnieniem liczby siedzib zarządów (SZ) spośród wszystkich 2000 firm z listy Forbes Global 2000. Przyjęto za literaturą, że graniczną liczbą SZ jest 4, postanowiono, że $4 S Z=1$. Dodatkowo, aby pozbyć się wartości ujemnych, do wszystkich otrzymanych wartości wskaźnika dodano wartość minimalną dla danego sektora, tak że wartość minimalna jest równa zero.

$$
s M W P=\left(\sum_{i=1}^{N} \frac{\frac{x_{i}-\bar{x}}{S D_{x}}}{N}+\frac{S Z s}{4}\right)+\left|\left(\sum_{i=1}^{N} \frac{\frac{x_{i}-\bar{x}}{S D_{x}}}{N}+\frac{S Z s}{4}\right)_{\text {min }}\right|
$$

gdzie:

x - wartości dla przychodów, zysków, aktywów oraz wartości rynkowej dla poszczególnych sektorów gospodarki,

x - wartość średnia przychodów, zysków, aktywów oraz wartości rynkowej dla poszczególnych sektorów gospodarki,

$\mathrm{s}$ - sektor gospodarki, 
$\mathrm{SD}_{\mathrm{x}}$ - odchylenie standardowe przychodów, zysków, aktywów oraz wartości rynkowej dla poszczególnych sektorów gospodarki,

$\mathrm{N}$ - liczba zmiennych $\mathrm{x}$,

SZ - liczba siedzib korporacji międzynarodowych w danym mieście,

$(\ldots)_{\min }$ - wartość minimalna dla danego sektora.

W celu określenia całościowego potencjału miasta dokonano zsumowania wartości potencjału dla poszczególnych sektorów (sMWP) i otrzymano wartość potencjału kontrolno-zarządczego dla danego miasta międzynarodowego wskaźnika potencjału MWP [2].

$$
M W P=\sum_{i=1}^{N} \mathrm{SMWP}_{\mathrm{i}}
$$

Otrzymany wskaźnik potencjału funkcji zarządczo-kontrolnych miast stanowi zatem nie sumę wartości przychodów, zysków, aktywów oraz wartości rynkowej dla poszczególnych firm mających siedzibę w danym mieście, ale sumę względną potencjału odnoszącego się do wartości potencjału dla poszczególnych sektorów miast europejskich. Według ekspertów znaczenie danego ośrodka w największym stopniu uzależnione jest od jego potencjału względem danego sektora (nawet sektora wykazującego niższe wartości wskaźników finansowych na tle ogółu analizowanych sektorów) niż od ogółu wyników finansowych zgromadzonych przez wszystkie sektory w tym mieście.

W literaturze przedmiotu można znaleźć inne wskaźniki potencjału ekonomicznego, np. Globalization and World Cities (GaWC) lub iloraz lokalizacji (Śleszyński, 2007). Przyjęty w niniejszej pracy wskaźnik jest dostosowany do dostępnych porównywalnych danych oraz bazuje na prostych metodach statystycznych możliwych powszechnie do wykorzystania w dalszych badaniach potencjału ekonomicznego miast.

W celu analizy przestrzennych zmian wartości MWP wykorzystano również metody grawitacyjne ( Kudłacz, 1981; Jażdżewska, 2006; Śleszyński, 2008; Dorocki, Struś, 2017).

\section{FUNKCJE KONTROLNO-ZARZĄDCZE W MIASTACH EUROPEJSKICH}

Analizując przestrzenne rozmieszczenie siedzib korporacji międzynarodowych, wyróżniono trzy regiony: Europę Zachodnią, wschodnią część Stanów Zjednoczonych Ameryki oraz wschodnią część Dalekiego Wschodu (Raźniak, Dorocki, Winiarczyk-Raźniak, 2015; 2016; 2017). Jednakże potencjał ekonomiczny miast wykazuje w historii gospodarczej świata dużą dynamikę. Do połowy XX wieku środek ciężkości przesuwał się z regionu Bliskiego Wschodu na północny zachód, aby następnie zmienić kierunek wschodni (Dobbs, Remes, Manyika, Roxburgh, Smit, Schaer, 2012). Od początku XXI wieku środek ekonomiczny miast zmierza w kierunku południowo-wschodnim, co według autorów raportu powodowane jest szybkim procesem urbanizacji w krajach rozwijających się, w szczególności Chin.

Wraz z rozwojem gospodarczym następuje proces urbanizacji prowadzący do dalszego pobudzenia gospodarki. Jednakże najwyższy wzrost nie następuje w największych ośrodkach, takich jak Bombaj czy Szanghaj, ale w kategorii miast średnich. 
Przykładem może być Foshan w Chinach czy Surat w Indiach. Powyższą tezę potwierdzają dotychczasowe badania potencjału kontrolno-zarządczego miast na świecie prowadzone przez autorów oraz analiza zmian rozmieszczenia SZ (Raźniak, Dorocki, Winiarczyk-Raźniak, 2017). Spośród trzech najważniejszych regionów KZ największy wzrost liczby SZ oraz potencjału międzynarodowego wskaźnika potencjału w latach 2006-2012 nastąpił w Azji (ok. 5\%), na Bliskim Wschodzie (ok. 2\%) oraz w Ameryce Południowej (ponad 1\%). Wzrost ten odbył się kosztem potencjału miast położonych w Europie i Ameryce Północnej (szczególnie USA, gdzie spadek udziału SZ oraz potencjału KZ wyniósł ok. 7\%) (tab. 1). Wydaje się zatem warte zbadania, czy również w przypadku Europy można zaobserwować podobny proces przesunięcia centrum potencjału KZ w kierunku wschodnim przy wzroście znaczenia krajów rozwijających się?

Tab. 1. Udział liczby SZ oraz potencjału KZ w poszczególnych regionach świata w latach 2006 i 2012

\begin{tabular}{|c|c|c|c|c|c|c|}
\hline \multirow{2}{*}{ Regiony } & \multicolumn{3}{|c|}{ SZ (\%) } & \multicolumn{3}{|c|}{ MWP (\%) } \\
\hline & 2006 & 2012 & $\Delta$ & 2006 & 2012 & $\Delta$ \\
\hline Azja (bez Bliskiego Wschodu) & 29,2 & 34,71 & 5,51 & 25,80 & 31,08 & 5,28 \\
\hline Bliski Wschód & 0,75 & 2,99 & 2,24 & 0,88 & 1,91 & 1,03 \\
\hline Ameryka Północna (bez USA) & 4,15 & 3,89 & $-0,26$ & 3,50 & 3,24 & $-0,26$ \\
\hline USA & 34,75 & 26,58 & $-8,17$ & 35,49 & 28,83 & $-6,66$ \\
\hline Europa & 25,95 & 24,94 & $-1,01$ & 30,59 & 28,90 & $-1,69$ \\
\hline Ameryka Południowa & 2,25 & 3,34 & 1,09 & 1,37 & 3,23 & 1,86 \\
\hline Australia & 1,85 & 2,19 & 0,34 & 1,83 & 2,11 & 0,28 \\
\hline Afryka & 1,1 & 1,35 & 0,25 & 0,55 & 0,70 & 0,15 \\
\hline
\end{tabular}

Źódło: obliczenia własne na podstawie danych Forbes Global 2000 (Forbes, 2013)

Analizując rozmieszczenie siedzib korporacji międzynarodowych w Europie w badanym okresie, można zauważyć ich koncentrację na obszarze tzw. niebieskiego banana (blue banana), czyli najbardziej rozwiniętego gospodarczo i technologicznie fragmentu kontynentu (Dorocki, 2011; Metaxas, Tsavdaridou, 2013). Analizując rozmieszczenie w analizowanych latach, można stwierdzić dużą inercję przestrzenną w lokalizacji SZ, powiązanych z największymi ośrodkami miejskimi Europy. Ponadto w badanym przedziale czasowym więcej nowych miast z SZ odnotowano na wschód od niebieskiego banana (dziewięć miast), podczas gdy na zachodzie doszukano się tylko trzech ośrodków miejskich (ryc. 1). Oczywiście, należy zwrócić uwagę na asymetryczność podziału powierzchni kontynentu poprzez przyjęcie kryterium delimitacji wschód-zachód, uwzględniając pryzmat europejskiego banana.

Jeśli odnieść się do zmiany liczby SZ oraz wartości potencjału KZ, uwidacznia się wzrost znaczenia obszarów peryferyjnych Europy, przede wszystkim wschodnich. Analizując wartości współczynnika zmienności w oparciu o liczbę SZ oraz wartości MWP w odniesieniu do współrzędnych geograficznych w latach 2006-2012, można stwierdzić niewielki wzrost koncentracji względem szerokości oraz duży wzrost rozproszenia względem długości geograficznej (ok. 28,7\% w przypadku SZ oraz ok. 47,9\% w przypadku MWP, gdzie 2006 rok = 100\%) (tab. 2). Tak duży wzrost zmienności w układzie horyzontalnym związany jest z decentralizacją obszaru europejskiego banana. W obrębie samego tego obszaru wyodrębniono 52 miasta z siedzibami korporacji w obydwu latach. Natomiast w 19 miastach siedziby odnotowano tylko w roku 2009, 
Ryc. 1. Miasta z siedzibami zarządów w latach 2006 i 2012

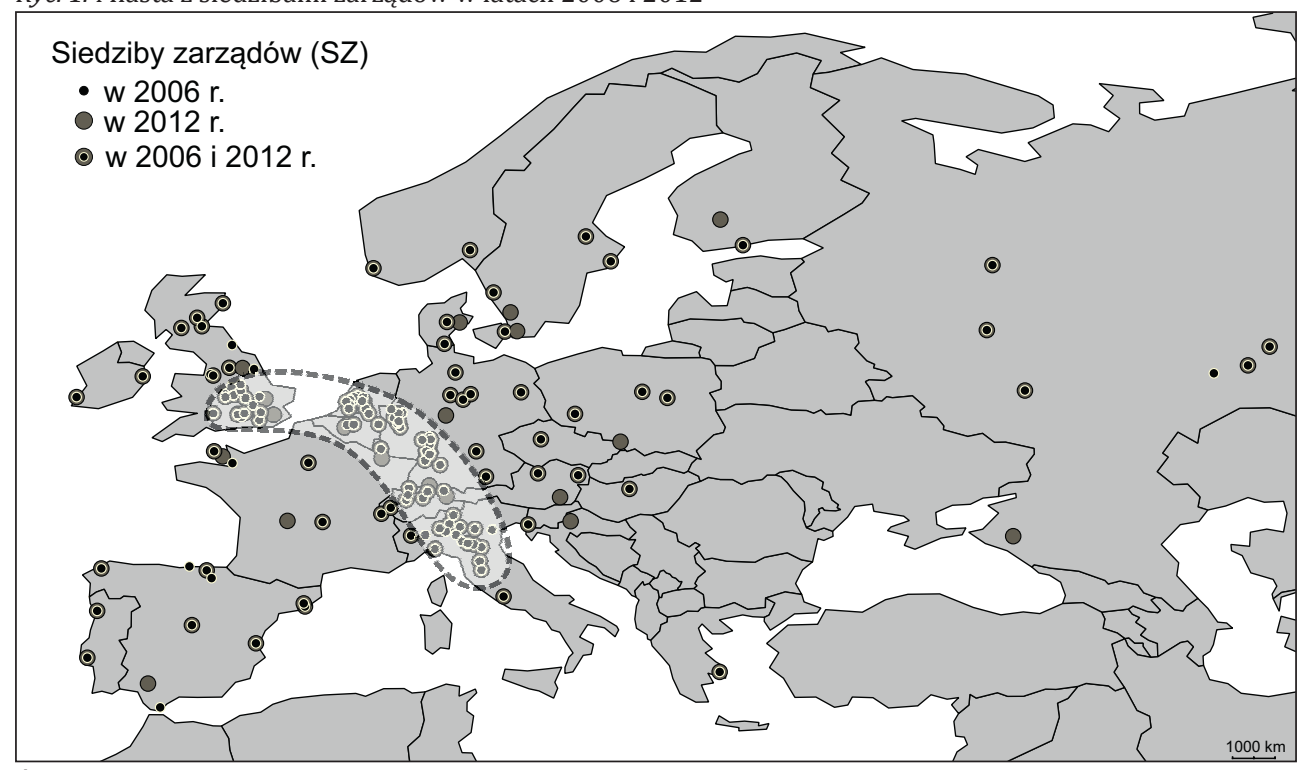

Źródło: obliczenia własne na podstawie danych Forbes Global 2000 (Forbes, 2013)

a w 11 przypadkach były to miasta, w których siedziby SZ zostały zlokalizowane po roku 2006. Tak więc bilans liczby miast z siedzibami SZ w badanym okresie był ujemny.

Poza obszarem niebieskiego banana $w$ badanych latach znajdowały się 72 miasta, z których w 50 przypadkach odnotowano siedziby SZ w obydwu latach (31 z tych miast znajdowało się na wschód od niebieskiego banana, a 19 - na zachód). Nowe ośrodki w 2012 roku pojawiły się głównie na wschodzie - 9 miast, podczas gdy na zachodzie tylko 4. Natomiast brak siedzib SZ w 2012 roku stwierdzono w 7 miastach zlokalizowanych na zachód od niebieskiego banana i tylko w 2 na wschód od niebieskiego banana. Pomimo tych przesunięć, z uwzględnieniem spadku udziału liczby SZ względem terenów peryferyjnych, średnia wartość potencjału KZ na obszarze niebieskiego banana w badanych latach wzrosła z 0,91 do 0,94, przy wzroście średniej dla peryferii z 0,74 do 0,93. Jak można zauważyć, w badanych latach nastąpiła wyraźna zmiana w przypadku wartości średnich danych MWP oraz ich zróżnicowania dla miast położonych w obrębie niebieskiego banana i peryferii (ryc. 2).

Biorąc jednak pod uwagę wartość testu na podobieństwo średnich, zarówno w 2006, jak i 2012 roku nie stwierdzono podstaw do odrzucenia hipotezy o braku istotnej różnicy między średnią wartością potencjału KZ dla miast zlokalizowanych na terenie niebieskiego banana i peryferiach na poziomie istotności $p=0,05$. Pomimo zauważalnych różnic w średnich wartościach MWP, zwłaszcza w 2006 roku, nie można twierdzić, że średni potencjał KZ w obszarze niebieskiego banana był większy niż w przypadku regionów peryferyjnych.

Również w ujęciu koncentracji potencjału KZ względem liczby SZ widać tylko niewielkie przesunięcie w przypadku miast o najmniejszym i największym potencjale (ryc. 2B). W 2012 roku w porównaniu do 2006 nastąpił wzrost koncentracji w miastach o niskim poziomie MWP oraz spadek koncentracji wśród miast o bardzo dużym potencjale MWP. Świadczyć to może o procesie wyrównywania się zróżnicowania koncentracji 
Ryc. 2. Wartości średnie oraz ich zróżnicowanie dla wartości MWP dla miast położonych w obszarze niebieskiego banana i peryferii (A) oraz zamiany koncentracji wartości MWP względem liczby SZ (B) w latach 2006 i 2012

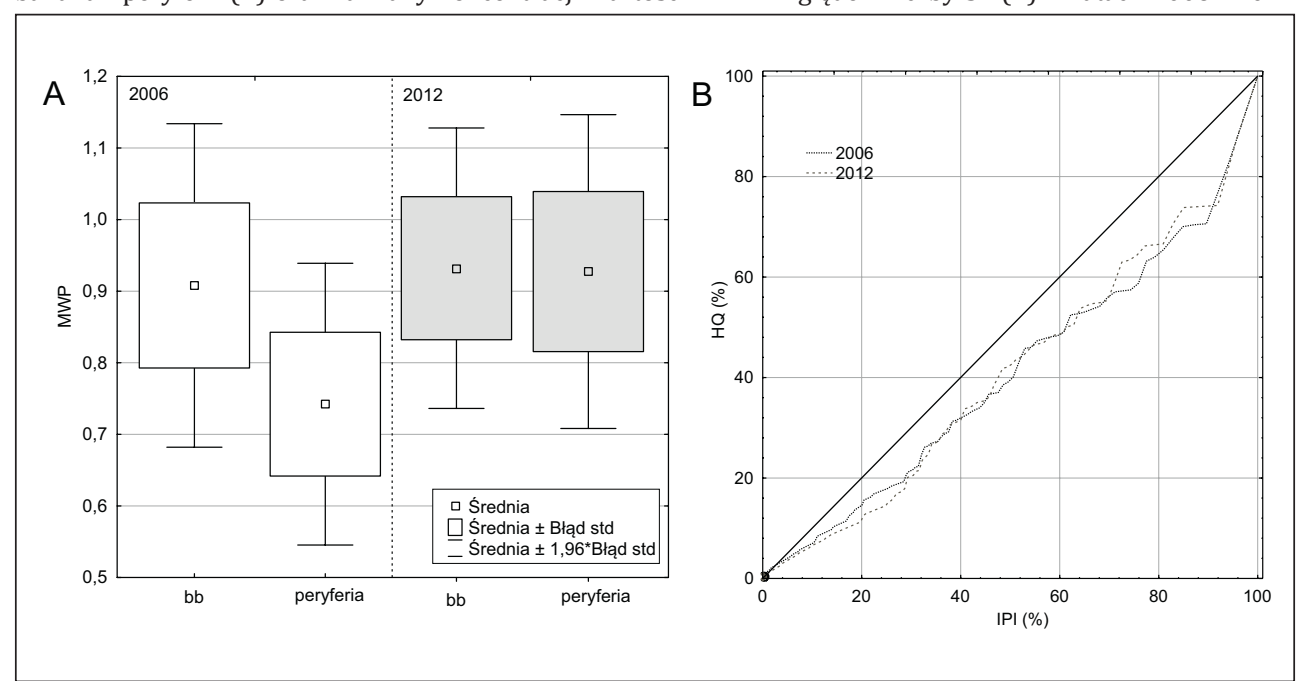

Źródło: obliczenia własne na podstawie danych Forbes Global 2000 (Forbes, 2013)

Ryc. 3. Rozmieszczenie środków ciężkości liczby siedzib zarządów oraz wartości MWP w latach 2006 i 2012

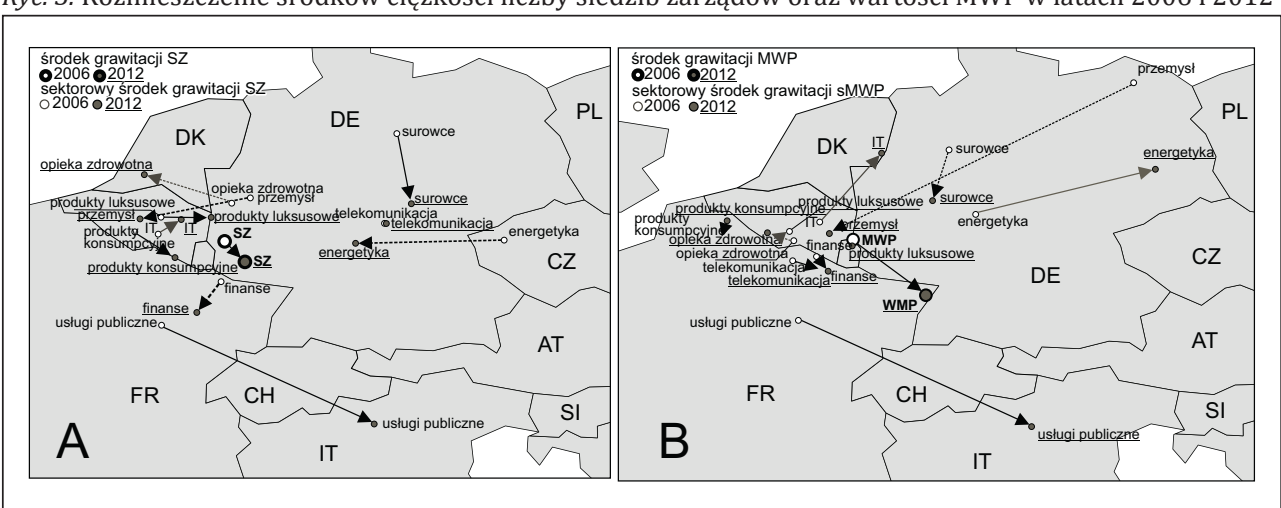

Źródło: obliczenia własne na podstawie danych Forbes Global 2000 (Forbes, 2013)

potencjału KZ w miastach europejskich. Zaznaczyć należy, że w przypadku ośrodków o najniższym i najwyższym potencjale (po ok. 10\% miast o największym i najmniejszym potencjale MWP) oraz w przypadku miast o średnich wartościach MWP nie odnotowano większych zmian koncentracji funkcji KZ.

Jednakże pomimo postępujących procesów decentralizacji potencjału KZ to właśnie na terenie niebieskiego banana zlokalizowane są środki ciężkości, zarówno dla liczby SZ, jak i dla wartości MWP w badanych latach (ryc. 3). Umiejscowione są w jednych z najbardziej uprzemysłowionych i najstarszych regionów przemysłowych Europy: Saary, Lotaryngii i Alzacji.

W badanym okresie większe zróżnicowanie w rozmieszeniu potencjału KZ w Europie wykazywały siedziby zarządów niż rozmieszczenie wartości MWP (tab. 2). Większe zróżnicowanie zaobserwowano w przypadku długości geograficznej niż w przypadku 
szerokości. Jednakże to właśnie wartości MWP względem długości geograficznej (przy spadku zróżnicowania w przypadku szerokości geograficznej) wykazały znaczniejszy wzrost zróżnicowania niż SZ. Świadczy to o powolnym rozlewaniu się potencjału KZ w Europie, głównie w kierunku wschodnim. Owe zmiany mogą nawiązywać do teorii żółtego banana (yellow banana) zakładającej, że rozwój społeczno-gospodarczy w Europie będzie przybierał kierunek Paryż-Warszawa i sięgał dalej na wschód (Hospers, 2003).

Tab. 2. Współczynnik zmienności w oparciu o wartości liczby siedzib zarządów (SZ) oraz międzynarodowego wskaźnika potencjału (MWP) w latach 2006 i 2012

\begin{tabular}{|l|c|c|c|c|c|c|}
\hline & \multicolumn{2}{|c|}{2006} & \multicolumn{2}{c|}{2012} & \multicolumn{2}{c|}{$2006-2012(2006=100 \%)$} \\
\hline & $\varphi$ & $\lambda$ & $\varphi$ & $\lambda$ & $\Delta \varphi$ & $\Delta \lambda$ \\
\hline SZ & 2,50 & 2,52 & 2,22 & 3,24 & $-11,12$ & 28,66 \\
\hline MWP & 0,97 & 1,55 & 0,91 & 2,29 & $-5,87$ & 47,86 \\
\hline
\end{tabular}

$\varphi$ - szerokość geograficzna, $\lambda$ - długość geograficzna, $\Delta$ - różnica w latach 2006-2012

Źródło: obliczenia własne na podstawie danych Forbes Global 2000 (Forbes, 2013)

Analizując zmiany, jakie zaszły w rozmieszczeniu centroidów w latach 2006 i 2012, można zauważyć, że w obu przypadkach przesunięcie położenia punktów odbyło się w kierunku południowo-wschodnim. W przypadku SZ było ono niewielkie - ok. 0,5 stopnia, natomiast w przypadku wartości MWP wyniosło ok. 1 stopnia szerokości i 2 stopni długości geograficznej. Różnica ta dowodzi, że pomimo małej zmiany lokalizacji SZ nastąpiła znacząca zmiana w potencjale KZ tych siedzib.

Jeśli wziąć pod uwagę centroidy sektorowe, największe przesunięcie na południowy wschód odnotowały firmy z sektora usług publicznych. Również centroidy wykreślone na podstawie liczby SZ firm z sektorów produktów luksusowych i konsumpcyjnych w badanym okresie przesunięte zostały w kierunku wschodnim. Przemieszczenie tych sektorów wiązało się z rozwojem konsumpcji i sektora usług w krajach rozwijających się na wschodzie oraz południu Europy. Zauważono ponadto, iż siedziby sektora energetycznego $\mathrm{w}$ badanym okresie wykazały według ich liczby duże przesunięcie w kierunku południowym. W kierunku zachodnim przesunięte zostały środki ciężkości dla liczby SZ sektorów: przemysł, energetyka i finanse. Zmiana profilu przedsiębiorstw przemysłowych na bardziej zaawansowane technologicznie spowodowała reorientację czynników lokalizacji. Współczesny przemysł wymaga zaawansowanej technologicznie infrastruktury i zaplecza naukowego. Ważnym elementem jest także pozyskanie kapitału inwestycyjnego, który w przypadku nowych rozwiązań obarczony jest dużym ryzykiem. Podobnie przemysł energetyczny odchodzi od „brudnych” technologii i staje się coraz bardziej zaawansowany technologicznie. Ważnym czynnikiem kształtującym rozwój przemysłu energetycznego jest polityka poszczególnych krajów Unii Europejskiej (Gullberg, 2013). Jednakże nadal sektory surowców oraz energetyki pozostają domeną Europy Wschodniej.

Sektorem, którego środek grawitacji według liczby SZ jako jedyny odnotował przesunięcie w kierunku północno-zachodnim, była opieka zdrowotna. Sektor ten jest obecnie - obok branży IT - najbardziej innowacyjnym działem gospodarki. Zarówno postęp naukowy, jak i procesy demograficzne (m.in. starzenie się społeczeństwa) wpływają na gwałtowny rozwój IT (Dorocki, 2014). Również i w tym przypadku współcześnie o lokalizacji centrów decyzyjnych w głównej mierze przesądza poziom zaawansowania 
regionu w sferze nauki i badań (Dorocki, Boguś, 2014). Dlatego siedziby firm sektora life sciences wykazują dużą koncentrację w regionach o dużym potencjale HRST (human resources in science and technology) i bliskości instytucji B + R oraz o dużym potencjale inwestycyjnym. Prowadzi to do powstawania klastrów biotechnologicznych (Dorocki, Jastrzębski, 2012), z których jeden z największych na świecie obejmuje prawie całą Europę Zachodnią (Site Selection for Life Sciences Companies in Europe, 2016).

Centroidy pozostałych innowacyjnych sektorów (telekomunikacja i IT) wykazały dużą stabilność. Środek grawitacji dla liczby SZ sektora IT przesunął się nieznacznie na północny wschód, natomiast centroid telekomunikacji pozostał prawie na niezmienionej pozycji geograficznej.

Środek ciężkości dla wartości MWP wyraźnie przesunął się w kierunku południowo-wschodnim. Podobnie jak w przypadku grawitacji SZ, największego przeskoku w kierunku wschodnim dokonał sektor usług publicznych. Następną branżą, której centroid przesunął się wyraźnie na wschód, jest energetyka. Sektor ten w obydwu latach zlokalizowany był na wschodzie Europy i pomimo spadku liczby SZ powstały w tej części kontynentu silne podmioty międzynarodowe (np. PKN Orlen, OMV Petrom). Natomiast największe przesunięcia na zachód w odniesieniu do potencjału MWP odnotował przemysł. Wynikało to głównie z restrukturyzacji przemysłu na wschodzie Europy oraz rozwoju nowych technologii, wymagających zarówno zaplecza kapitałowego, jak i odpowiedniej infrastruktury. Obserwując sektor IT, zauważono jego przesunięcie na północny wschód. Przemysł high-tech w Europie przeżywa spadek we wszystkich kluczowych

Ryc. 4. Liczba SZ w miastach Europy w latach 2006 i 2012

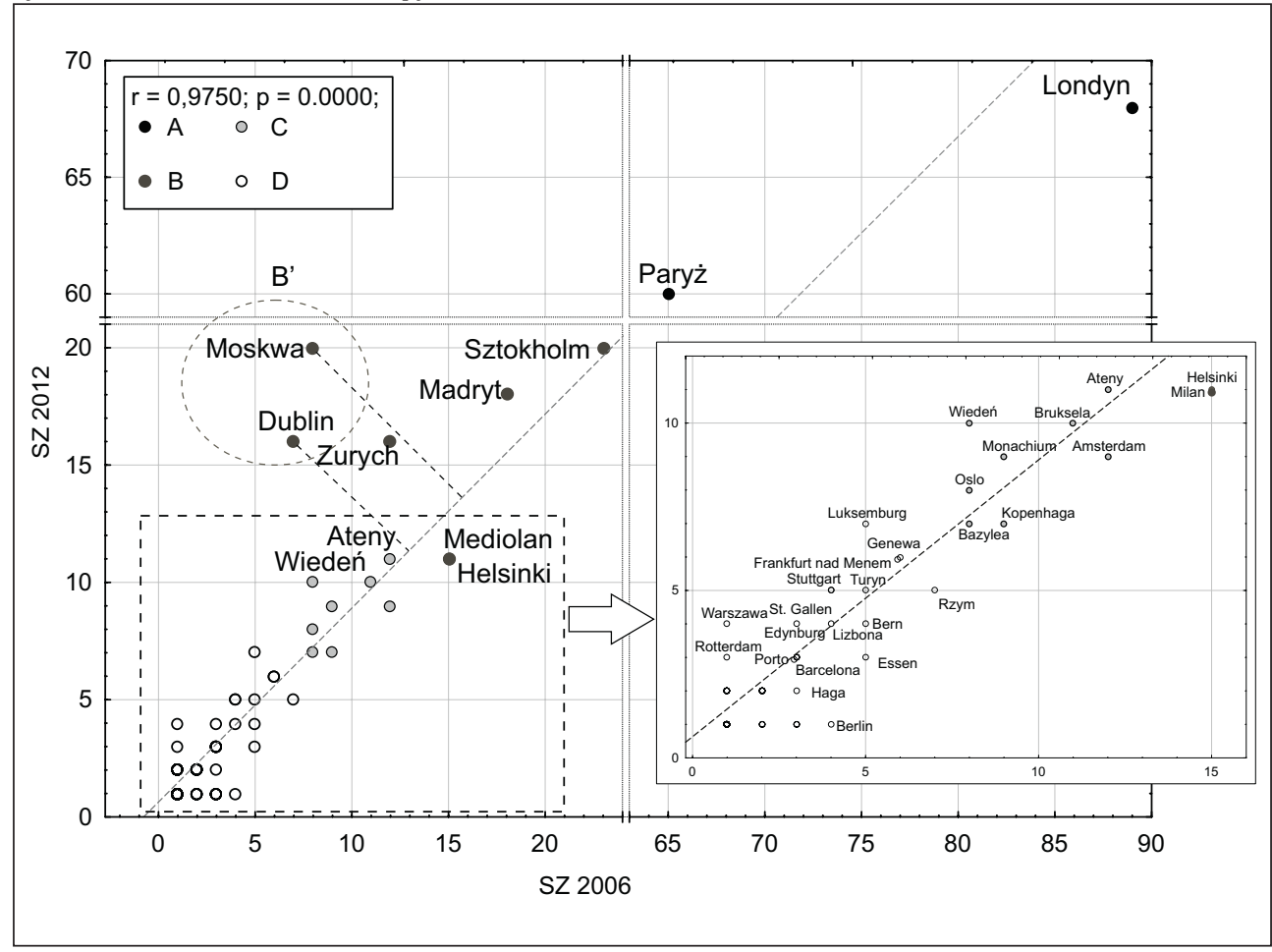

Źródło: obliczenia własne na podstawie danych Forbes Global 2000 (Forbes, 2013) 
segmentach. Firmy europejskie stanowią mniej niż 10\% w globalnej sprzedaży na świecie w sektorze technologii informacyjnych i komunikacyjnych (ICT). Przedsiębiorstwa z USA i Azji zdominowały rynek światowy i dążą do drenażu Europy. Przykładem może być przejęcie UK's Autonomy przez Hewlett-Packard czy Nokii przez Microsoft. Dodatkowymi czynnikami wpływającymi na zastój w europejskim sektorze IT jest brak kapitału inwestycyjnego oraz niedobór wykształconych kadr.

W pozostałych przypadkach przesunięcie było niewielkie i odbywało się w obrębie niebieskiego banana. Należy zatem wnioskować, że o przemieszczeniu centroidów grawitacji w przypadku rozmieszczenia SZ jak i potencjału MWP zadecydowały gównie 3 sektory: usługi publiczne, energetyka i przemysł. Usługi publiczne najsilniej związane są z konsumentami i przesunięcie grawitacji na wschód wynikało z rozwoju społeczno-gospodarczego oraz dużej chłonności konsumpcyjnej rynku Europy Wschodniej. Natomiast w przypadku przemysłu o zmianie położenia punktu grawitacji w kierunku zachodnim zadecydował wzrost znaczenia przemysłu wysokich technologii, które są domeną gospodarki Europy Zachodniej. Jest to głównie przemysł motoryzacyjny, kosmiczny, chemiczny i obronny. Innym czynnikiem wpływającym zarówno na branżę przemysłową, jak i energetyczną jest protekcyjna polityka krajów. Doświadczenia światowego kryzysu finansowego oraz niestabilna sytuacja na europejskim rynku energetycznym wpływają na prowadzenie polityki mającej na celu ograniczenie inwestycji zagranicznych oraz ochronę własnego rynku.

Analizując zmiany w potencjale zarządczo-kontrolnym poszczególnych miast, można zauważyć, że również w tym ujęciu nastąpiły w badanym okresie wyraźnie zmiany hierarchii miast w Europie. Spośród wszystkich ośrodków miejskich największy udział SZ skupiły Londyn i Paryż, zaliczone do typu A (światowe centra kontrolno-zarządcze). Aglomeracje te w 2006 roku posiadały prawie 30\% wszystkich SZ w Europie, a w 2012 roku - 25\%. Odnotowany spadek wynikał głównie z redukcji udziału SZ w Londynie. Największy wzrost liczby SZ w badanym okresie wystąpił natomiast w Moskwie i Dublinie, które dołączyły do grupy miast posiadających powyżej 15 SZ (typ B). Do tej grupy w 2012 roku należały m.in. Sztokholm, Madryt i Zurich (ryc. 4). W grupie tej w 2006 roku znalazły się Mediolan i Helsinki, jednakże zanotowały one spadek liczby SZ.

Następną grupę według liczby SZ tworzyło 8 miast, których średnia liczba SZ wynosiła ok. 10 i różnice w ich liczbie w badanych latach były niewielkie. Do tego typu ośrodków (typ C) należały: Bruksela, Ateny, Amsterdam, Wiedeń, Monachium, Oslo, Bazylea i Kopenhaga. Spośród wymienionych miast największy wzrost charakteryzował Wiedeń. W grupie C znalazły się kraje o najniższej liczbie SZ (poniżej 6 SZ). Miastami na styku tych dwóch grup były: Luksemburg, Frankfurt nad Menem i Genewa. Łącznie był to zespół przeszło 100 miast, z których największy wzrost liczby SZ odnotowała Warszawa, jednocześnie będąca zdecydowanie dominującym ośrodkiem w Polsce w skali światowej i krajowej (Śleszyński, 2015), a największy spadek miał niemiecki Berlin.

Zatem w odniesieniu do liczby SZ można zauważyć spadek ich liczby w takich wielkich aglomeracjach, jak: Londyn, Mediolan, Helsinki, Amsterdam, Kopenhaga, Rzym, Bern, Essen, Haga czy Berlin. Pojawili się natomiast nowi liderzy, np. Moskwa, Dublin, Zurich czy Warszawa.

W przypadku wartości wskaźnika MWP większe zróżnicowanie stwierdzono w potencjale kontrolno-zarządczym w Europie. Również w tym ujęciu najwyższe wartości odnotowały Londyn i Paryż, z tą różnicą, że to stolica Francji w 2012 roku wyprzedziła Londyn (ryc. 5). Wynikało to zarówno z centralizacyjnego charakteru Paryża (Paryż 
Ryc. 5. Wartości MWP w miastach Europy w latach 2006 i 2012

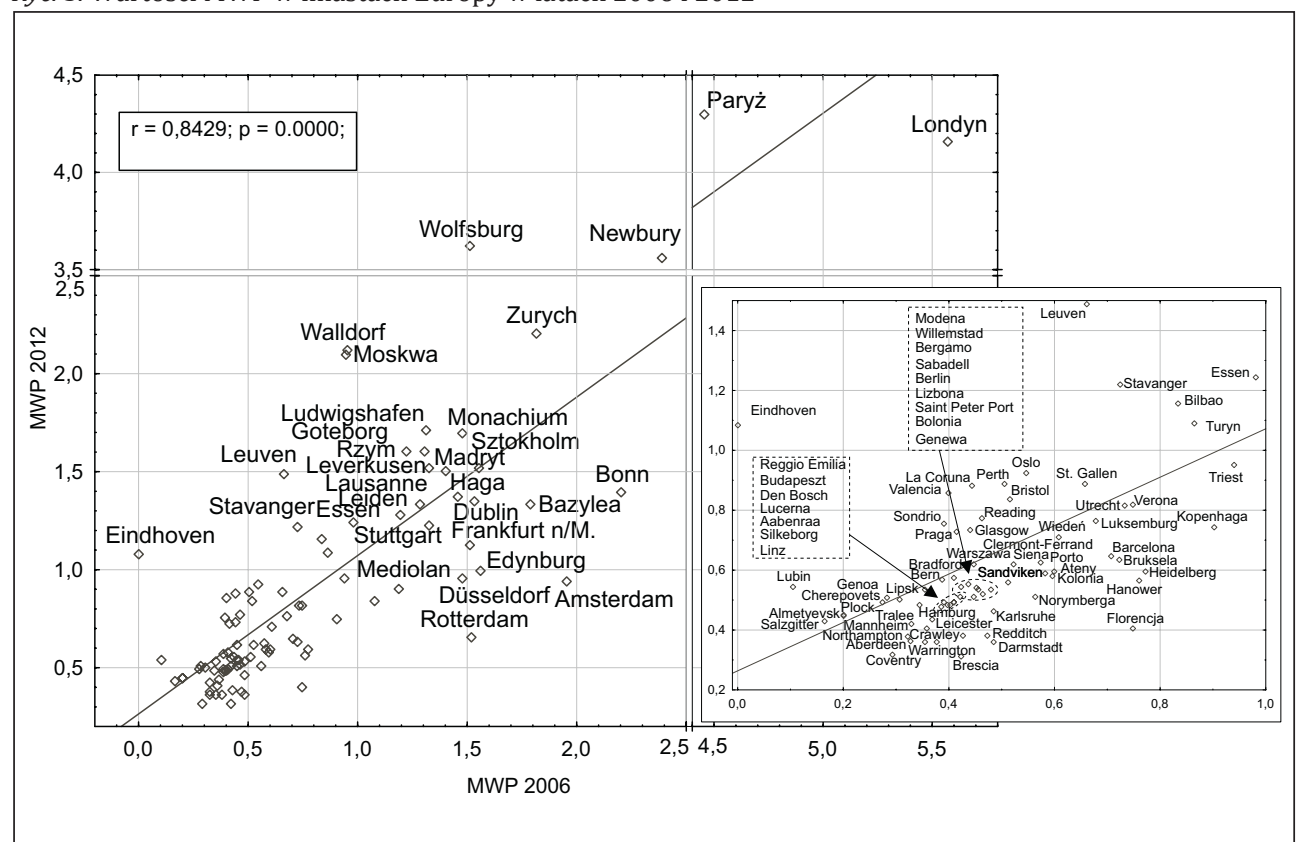

Źródło: obliczenia własne na podstawie danych Forbes Global 2000 (Forbes, 2013)

i „pustynia francuska”), jak i polityki Wielkiej Brytanii dążącej do większej izolacji w stosunku do kontynentu.

W grupie miast posiadających wysokie wartości wskaźnika MWP znalazły się zarówno duże ośrodki z kilkudziesięcioma SZ, np. Amsterdam, Zurych, Sztokholm czy Madryt, jak i miasta, o których potencjale decydowała jedna wielka korporacja, np. Newbury (Vodafone), Wolfsburg (Volkswagen Group). Oprócz tych monolideralnych miast, wysokich wartości MWP i dużego wzrostu doszukano się także w Zurichu, Walldorfie (SAP SE) i Moskwie. W czołówce znalazły się zatem zarówno ośrodki zaliczane do europejskiego rdzenia miast (blue banana), jak i peryferii.

W większości przypadków w okresie 2006-2012 nastąpił spadek wartości MWP, zwłaszcza w miastach o najniższym potencjale (<1 MWP). W przeważającej większości spadek dotyczył miast Europy Zachodniej (Niemcy, kraje Beneluksu, Wielka Brytania). Wzrost potencjału odnotowały natomiast takie miasta, jak: Leuven (Anheuser-Busch InBev SA/NV), Eindhoven (Philips, DAF Trucks and Brabantia) czy Stavanger (Statoil). W przypadku tych ośrodków głównym czynnikiem wzrostu był rozwój zlokalizowanych tam firm. Jednakże należy zaznaczyć, że oprócz działalności produkcyjnej w ośrodkach tych rozwinęły się klastry związane z dominującą gospodarką. I tak w Leuven obok przemysłu spożywczego działają spółki spin-off z branży biotechnologicznej. W Eindhoven, gdzie Philips przyciąga inne firmy z branży high-tech oraz inicjuje rozwój nowych przedsiębiorstw poprzez inwestycje w badania (jedna trzecia wydatków krajowych na B + R), tworzone są start-upy (High Tech Campus Eindhoven). Wśród miast wykazujących wzrost wartości MWP znalazły się głównie miasta Europy Południowej (Hiszpania, Włochy), Szkocji oraz Europy Wschodniej (Praga, Lubin, Płock) (ryc. 5 i tab. 3). 
Tab. 3. Wartość wskaźnika MWP w latach 2006-2012

\begin{tabular}{|l|c|c|c|}
\hline \multirow{2}{*}{ OM } & \multicolumn{2}{|c|}{ MWP } & \multirow{2}{*}{ Różnica 2012-2006 } \\
\cline { 2 - 4 } & 2006 & 4,3 & $-0,16$ \\
\hline Paryż & 4,46 & 4,16 & $-1,41$ \\
\hline Londyn & 5,57 & 3,62 & 2,11 \\
\hline Wolfsburg & 1,51 & 3,56 & 1,17 \\
\hline Newbury & 2,39 & 2,21 & 0,39 \\
\hline Zurych & 1,82 & 2,12 & 1,16 \\
\hline Moskwa & 0,96 & 2,1 & 1,16 \\
\hline Walldorf & 0,94 & 1,71 & 0,4 \\
\hline Ludwigshafen & 1,31 & 1,7 & 0,22 \\
\hline Monachium & 1,48 & 1,6 & 0,38 \\
\hline Rzym & 1,22 & 1,6 & 0,3 \\
\hline Goteborg & 1,3 & 1,52 & 0,19 \\
\hline Madryt & 1,33 & 1,52 & $-0,03$ \\
\hline Sztokholm & 1,55 & 1,51 & 0,11 \\
\hline Leverkusen & 1,4 & 1,49 & 0,83 \\
\hline Leuven & 0,66 & 1,4 & $-0,81$ \\
\hline Bonn & 2,2 & 1,37 & $-0,09$ \\
\hline Haga & 1,46 & 1,35 & $-0,19$ \\
\hline Dublin & 1,54 & 1,34 & 0,05 \\
\hline Lozanna & 1,28 & 1,33 & $-0,46$ \\
\hline Bazylea & 1,79 & & \\
\hline & & & \\
\hline
\end{tabular}

Źródło: obliczenia własne na podstawie danych Forbes Global 2000 (Forbes, 2013)

\section{PodsumoWANIE}

Współcześnie zauważalny jest wzrost znaczenia funkcji kontrolno-zarządczych w ekonomii miast i pozycji międzynarodowej poszczególnych krajów. Pomimo procesów globalizacji i delokalizacji produkcji instytucje kierownicze oraz podmioty strategiczne (np. ośrodki badawcze) wykazują dużą inercję przestrzenną. Zmiany lokalizacji międzynarodowych siedzib zarządów są zatem jednym ze wskaźników dzisiejszych procesów gospodarczych. Ich historyczna struktura ulega transformacji w odpowiedzi na zachodzące zmiany społeczno-gospodarcze, dostosowując się do nowych uwarunkowań. Przykładem tych zmian w Europie może być osłabienie znaczenia historycznego, nawiązującego jeszcze do średniowiecznych szlaków handlowych, obszaru tzw. blue banana.

Współcześnie, głównie w wyniku rozwoju obszarów Europy Środkowo-Wschodniej oraz postępującej integracji europejskiej (wzrastającej w kierunku wschodnim i południowym), następuje delokalizacja siedzib wielu firm z zachodu na wschód oraz wzrasta znaczenie lokalnych przedsiębiorstw w krajach rozwijających się. Zmiana potencjału kontrolno-zarządczego i liczby siedzib zarządów jest bardzo zróżnicowana i zależy od sektora działalności gospodarczej. Największe zmiany w lokalizacji $\mathrm{w}$ badanym okresie odnotowano w przypadku usług publicznych oraz produktów luksusowych i konsumpcyjnych. Wydaje się, że zmiana w przypadku tych sektorów była wywołana czynnikami lokalizacji względem wzrostu popytu na produkty zagraniczne 
oraz specyficznych postaw konsumenckich w regionach południowych i wschodnich Europy (Huddleston, Good, Stoel, 2001).

Przykładem zmiany lokalizacji siedzib zarządów względem bazy surowcowej jest sektor energetyczny, którego centroid przesunął się na wschód (głównie dzięki wkroczeniu na rynek globalny firm z krajów Europy Wschodniej - Rosji i Ukrainy), jednakże potencjał finansowy został w tym samym czasie przesunięty na zachód, co wiązało się z rozwojem nowych źródeł energii oraz lokalizacją kapitału. Spośród innych sektorów jedynie przemysł i opieka zdrowotna odnotowały w latach 2006-2012 relokację centrów siedzib zarządów i funkcji kontrolno-zarządczej wyraźnie na zachód. Wynikało to z silnych powiązań przemysłu i sektora ochrony zdrowia z zapleczem naukowo-badawczym oraz dostępności kapitału inwestycyjnego.

W miastach, w których zlokalizowane są siedziby największych korporacji, powstają klastry produkcyjne przyciągające inne firmy oraz kreujące nowe podmioty. Ważnym czynnikiem stymulującym rozwój w tych branżach są również ośrodki naukowe i badawcze. Dlatego firmy z sektora high-tech, pomimo postępującej penetracji rynków peryferyjnych, nie wykazują delokalizacji swoich siedzib. Jedynie w przypadku prób zdominowania rynku poprzez przejęcie lokalnych firm i marek może zaistnieć taka pozorna zmiana.

Przedstawione powyżej procesy wpłynęły na zmianę hierarchii krajów i miast w Europie pod względem potencjału kontrolno-zarządczego. Ogólnie można przyjąć, że nastąpił wzrost znaczenia miast w krajach rozwijających się (Rosja, Polska). Szczególnie widoczne jest to pod względem liczby siedzib zarządów. Jednakże przemieszczenie kapitału nie jest aż tak wyraźne i w dalszym ciągu takie kraje jak Niemcy czy Wielka Brytania pozostają niezaprzeczalnymi kontynentalnymi liderami. Owa dysproporcja szczególnie widoczna jest w przypadku takich ośrodków, jak Paryż i Londyn. Spośród wszystkich krajów Europy Zachodniej największy kryzys pod względem funkcji kontrolno-zarządczych odnotowała Wielka Brytania i Londyn. Wydaje się, że współczesne decyzje polityczne mogą wpłynąć na dalszy proces osłabienia znaczenia tego kraju w stosunku do kontynentu.

W pracy pominięto $\mathrm{w}$ dużym stopniu uwarunkowania polityczne oraz wpływ kryzysu na zmiany lokalizacji światowych centrów zarządczo-decyzyjnych, co według autorów wymaga odrębnego szczegółowego opracowania.

\section{Literatura \\ References}

Beaverstock, J.V., Smith R.G., Taylor P.J. (1999). A roster of world cities. Cities, 16(6), 445458. DOI:10.1016/S0264-2751(99)00042-6

Begg, I. (1999). Cities and competitiveness. Urban Studies, 36(5-6), 795-810.

Brunet, R. (1989). Les Villes européennes, Rapport pour la DATAR, Délégation a l'Aménagement du Territoire et a l'Action Régionale, under the supervision of Roger Brunet, with the collaboration of Jean-Claude Boyer et al., Groupement d'Intéret Public RECLUS. Paris: La Documentation Française.

Csomós, G. (2013). The Command and Control Centers of the United States (2006/2012): An Analysis of Industry Sectors Influencing the Position of Cities. Geoforum, 12(50), 241-251. DOI: 10.1016/j.geoforum.2013.09.015

Csomós, G., Tóth, G. (2016). Featured Graphic. Modelling the shifting command and control function of cities through a gravity model based bidimensional regression analysis. Environment and Planning A, 48(4), 613-615. DOI: 10.1177/0308518X15621632 
Dobbs, R., Remes, J., Manyika, J., Roxburgh, Ch., Smit, S., Schaer, F. (2012) (2017, 19 grudnia). Urban world: Cities and the rise of the consuming class. Pozyskano z http://www.mckinsey.com/ /media/McKinsey/Global\%20Themes/Urbanization/Urban\%20world\%20 Cities\%20and\%20the $\% 20$ rise $\% 20$ of\%20the\%20consuming\%20class/MGI_Urban_world_ Rise_of_the_consuming_class_Full_report.ashx

Domański, B. (2004). Local and regional embeddedness of foreign industrial investors in Poland. Prace Geograficzne, 114, 37-54.

Dorocki, S. (2011). Wpływ kryzysu gospodarczego na przemiany struktur regionalnych Francji. Prace Komisji Geografii Przemysłu Polskiego Towarzystwa Geograficznego, 17, 67-86.

Dorocki, S. (2014). Contemporary Trends in the Development of the Pharmaceutical Industry in the World. Prace Komisji Geografii Przemysłu Polskiego Towarzystwa Geograficznego, 25, 108-131.

Dorocki, S., Boguś, M. (2014). Regional Variety of Biotechnology Development in Asia. Procedia Social and Behavioral Sciences, 120, 197-212. DOI: 10.1016/j.sbspro.2014.02.097

Dorocki, S., Jastrzębski, J. (2012). Regionalne zróżnicowanie rozwoju biotechnologii w Europie. Prace Komisji Geografii Przemysłu Polskiego Towarzystwa Geograficznego, 20, 67-94.

Dorocki, S., Struś, P. (2017). Przestrzenne zróżnicowanie dynamiki rozwoju lokalnegow Małopolsce na podstawie wybranych cech społeczno-gospodarczych. Prace Komisji Geografii Przemysłu Polskiego Towarzystwa Geograficznego, 31(2), 7-25. DOI: 10.24917/20801653.312.1

Friedmann, J. (1986). The world city hypothesis. Development and Change, 17(1), 69-83. DOI: $10.1111 / \mathrm{j} .1467-7660.1986 . t b 00231 . x$

Forbes (2013, 15 listopada). Pozyskano z www.forbes.com

Gorzelak, G. (1996). The Regional Dimension of Transformation in Central-Europe. London.

Gullberg, A.T. (2013). The political feasibility of Norway as the 'green battery' of Europe. Energy Policy, 57, 615-623. DOI: 10.1016/j.enpol.2013.02.037

Hospers, G.J. (2003). Beyond the Blue Banana? Structural change in Europe's geo-economy. Intereconomics, 38, 76-85. DOI: 10.1007/BF03031774

Huddleston, P., Good, L., Stoel, L. (2001). Consumer ethnocentrism, product necessity and Polish consumers' perceptions of quality. International Journal of Retail \& Distribution Management, 29, 236-246. DOI: 10.1108/09590550110390896

Jażdżewska, I. (2006). Zmiany położenia środka ciężkości miast i ludności miejskiej w Polsce w XX wieku. Przegląd Geograficzny, 78(4), 561-574.

Kilar, W. (2009). Korporacje informatyczne jako element struktury metropolii. Studia Komitetu Przestrzennego Zagospodarowania Kraju Polskiej Akademii Nauk, 125, 136-153.

Kincses, Á., Nagy, Z., Tóth, G. (2013). The Spatial Structures of Europe. Acta Geographica Slovenica, 53(1), 43-70. DOI: 10.3986/AGS53103

Kramar, H. (2006). Economic convergence on different spatial levels: the conflict between cohesion and growth. Raumforschung und Raumordnung, 1, 18-27.

Kudłacz, T. (1981). Zastosowanie metody grawitacji i grafów do hierarchizacji jednostek przestrzennych. Przegląd Geograficzny, 53(1), 519-534.

Metaxas, T., Tsavdaridou, M. (2013). From 'blue banana' to 'red octopus' and the development of Eastern and southern european cities: Warsaw and Lisbon. Regional and Sectoral Economic Studies, 13(1), 15-31.

Ni, P., Taylor, P.J., Derudder, B. (2011). The global city process score. W: P.J. Taylor, P. Ni, B. Derudder, M. Hoyler, J. Huang, F. Witlox (red.). Global Urban Analysis: a Survey of Cities in Globalization. London: Earthscan.

Parkinson, M., Hutchins, M., Simmie, J., Clark, G., Verdonk, H. (2004). Competitive European cities: where do the core cities stand? London: ODPM.

Raźniak, P., Dorocki, S., Winiarczyk-Raźniak, A. (2015). Ranga miasta w świetle syntetycznego wskaźnika stabilności gospodarczej. Studia Miejskie, 18, 119-130.

Raźniak, P., Dorocki, S., Winiarczyk-Raźniak, A. (2016). Kryzys gospodarczy a funkcje kontrolno-zarządcze miast w dobie globalizacji. OPTIMUM. Studia Ekonomiczne, 79(1), 100-117.

Raźniak, P., Dorocki, S., Winiarczyk-Raźniak, A. (2017). Permanence of the economic potential of cities based on sector development. Chinese Geographical Science, 27(1), 123-136. DOI: $10.1007 / \mathrm{s} 11769-017-0850-5$ 
Raźniak, P., Dorocki, S., Winiarczyk-Raźniak, A. (2018). Eastern European cities as command and control centres in time of economic crisis. Acta Geographica Slovenica, 58(2), 101-110. DOI: 10.3986/AGS.3124

Raźniak, P., Dorocki, S., Winiarczyk-Raźniak, A., Płaziak, M., Szymańska, A.I. (2017). Zmiany pozycji ekonomicznej miast Europy Środkowo-Wschodniej w przypadku kryzysu dominującego sektora. Ekonomista, 1, 67-83.

Sassen, S. (2000). The Global City: Strategic Site/New Frontier. American Studies, 41(2/3), 79-95.

Site Selection for Life Sciences Companies in Europe 2016 (2017, 19 grudnia). Pozyskano z https://assets.kpmg.com/content/dam/kpmg/ch/pdf/site-selection-for-life-sciences-companies-europe-en.pdf

Storper, M. (1995). The resurgence of regional economies, ten years later: the region as a nexus of untraded interdependencies. European Urban and Regional Studies, 2, 191-221.

Śleszyński, P. (2007). Gospodarcze funkcje kontrolne w przestrzeni Polski. Prace Geograficzne, 213.

Śleszyński, P. (2008). Ocena powiązań gospodarczych i kapitałowych między miastami. W: K. Saganowski, M. Zagrzejewska-Fiedorowicz, P. Żuber (red.). Ekspertyzy do Koncepcji Przestrzennego Zagospodarowania Kraju 2008-2033. Tom I. Warszawa: Ministerstwo Rozwoju Regionalnego, 335-391.

Śleszyński, P. (2015). Economic control functions in Poland in 2013. Geographia Polonica, 88(4), 701-708.

Tóth, G, Csomós, G. (2016). Mapping the position of cities in corporate research and development through a gravity model-based bidimensional regression analysis. Regional Statistics, 6(1), 217-220. DOI: 10.15196/RS06111

Tóth, G., Nagy, Z. (2017). The world's economic centre of gravity. Regional Statistics, 6(2), 177180. DOI: $10.15196 /$ RS06210

Wegener, M., Kunzmann, K.R (1996). New Spatial Patterns of European Urbanisation. W: D. Pumain, T. Saint-Julian (red.). Urban networks in Europe. Paris: John Libbey, 7-18.

Zioło, Z. (2006). Zróżnicowanie światowej przestrzeni przemysłowej w świetle koncentracji siedzib zarządów wiodących korporacji. Prace Komisji Geografii Przemysłu Polskiego Towarzystwa Geograficznego, 8, 9-26.

Piotr Raźniak, dr, adiunkt, Instytut Geografii, Uniwersytet Pedagogiczny w Krakowie. Do jego zainteresowań badawczych należą problemy gospodarcze miast, hierarchie miast światowych, problemy funkcjonowania obszarów metropolitalnych oraz funkcje kontrolno-zarządcze miast kreowane przez korporacje.

Piotr Raźniak, Ph.D., assistant professor at the Institute of Geography of the Pedagogical University of Cracow, Poland. Corporations, hierarchies of world cities, problems of functioning of metropolitan areas, spatial structure of corporations and command and control functions of cities created by large corporations are included in his research interests.

\section{Adres/address:}

Uniwersytet Pedagogiczny w Krakowie

Instytut Geografii

Zakład Geografii Społeczno-Ekonomicznej

ul. Podchorążych 2, 30-084 Kraków, Polska

e-mail: prazniak@up.krakow.pl

Sławomir Dorocki, dr, absolwent studiów z zakresu geografii społeczno-ekonomicznej Uniwersytetu Pedagogicznego w Krakowie, doktor nauk humanistycznych w dyscyplinie historia (Instytut Europeistyki, Uniwersytet Jagielloński). Adiunkt w Instytucie Geografii Uniwersytetu Pedagogicznego w Krakowie. Jego zainteresowania badawcze skupiają się wokół problematyki regionów i procesów regionalizacji społeczno-gospodarczej, ze szczególnym uwzględnieniem zróżnicowania przestrzeni europejskiej oraz procesów integracji europejskiej i uwarunkowań historycznych oraz zastosowaniem metod komputerowych i statystycznych w badaniach nad zróżnicowaniem przestrzeni.

Sławomir Dorocki, Ph.D., Department of Entrepreneurship and Spatial Management, Institute of Geography, the Pedagogical University of Cracow. Sławomir Dorocki has graduated from the Pedagogical University of 
Cracow, MA degree in Geography, PhD in History (Institute of European Studies of the Jagiellonian University). Associate professor at the Pedagogical University of Cracow, Institute of Geography. His research interests are connected to regional problems and processes of socio-economic regionalisation, with particular emphasis on the diversity of Europe, processes of European integration, historical conditions, and application of computer and statistical methods in the study of diversity of space.

\section{Adres/address:}

Uniwersytet Pedagogiczny w Krakowie

Instytut Geografii

Zakład Przedsiębiorczości i Gospodarki Przestrzennej

ul. Podchorążych 2, 30-084 Kraków, Polska

e-mail: sdorocki@up.krakow.pl

Anna Winiarczyk-Raźniak, dr, adiunkt, Instytut Geografii, Uniwersytet Pedagogiczny w Krakowie. Do jej zainteresowań badawczych należą zagadnienia poziomu i jakości życia, rozwój i funkcjonowanie obszarów metropolitalnych, suburbanizacja, geografia społeczna krajów Ameryki Łacińskiej.

Anna Winiarczyk-Raźniak, Ph.D., assistant professor at the Institute of Geography of the Pedagogical University of Cracow. Her research interests include level and quality of life, development and problems of functioning of metropolitan areas, suburbanisation and social geography of Latin America.

\section{Adres/address:}

Uniwersytet Pedagogiczny w Krakowie

Instytut Geografii

Zakład Geografii Społeczno-Ekonomicznej

ul. Podchorążych 2, 30-084 Kraków, Polska

e-mail: arazniak@up.krakow.pl 